\title{
Project Financing in Laos' Hydropower for Export of Electricity to Thailand
}

\section{Xaypaseuth Phomsoupha}

Xaypaseuth Phomsoupha

\begin{abstract}
Laos, a mountainous and landlocked country, continues to exploit its hydropower potential for export of electricity to neighboring countries such as Thailand, Vietnam and Cambodia. Despite the great development potential and market opportunities both inside and outside the country, the scarcity of finance for public investment in the power generation sector has been a bottleneck for Lao hydropower. Private investment has therefore been sought and promoted through an independent power producer (IPP) approach which relies on the availability of project funds from the private sector. Currently, six privately-financed hydropower projects operated by private companies are exporting electricity to the grids of Laos' neighbors. Ten additional hydropower projects developed with private financing are now under construction, and several other projects now under consideration as to their technical feasibility are planned to achieve power-on by 2020 .
\end{abstract}

Key words: Project financing, limited recourse financing, hydropower, Laos

\section{Key Concepts of Project Financing}

Tn project finance, several key participants (host country, developer, off-taker(s), and financier) share risks associated with the project's development.

In financing a project, the host country is not required to provide any financial guarantee to other participants, but does provide contractual guarantees that certain conditions will be accorded to the project throughout the term of project construction and operation. A project is developed on a Build-Own-Operate-Transfer (BOOT) basis through a limited liability Special Purpose Company (SPC). Typically, around 70\% of the total project cost is sourced by the SPC from commercial banks as debt financing, with lenders relying upon future cash flow of the project for interest and debt repayment.

The main forms of security for lending banks are the concession agreement, the power purchase agreement(s), leasehold rights, predictable future cash flows, project insurances, and the assets and rights of the project company as set forth in the various project agreements. The remaining 30\% of total project cost is generally contributed by the shareholders of the SPC in the form of equity financing which is generally subject to lender recourse by the commercial banks if the project fails. Shareholders are generally not subject to claims to provide additional financial support to the project in excess of their equity commitments. This mode of financing, therefore, is referred to as 'Project Financing' or commonly known as limited recourse financing.

\section{Bankable Project Documents}

All hydropower projects in the Lao plan to export electricity to Thailand have been developed with project financing which requires project studies and agreements to be structured to the satisfaction of lending banks. The studies and agreements shall be completed and may be used by the SPC as collateral security against project debt incurred to commercial lenders.

Prospective lenders review the project documents to determine project financeability prior to signing financing agreements with the SPC. The developers, therefore, must take into account the requirements of prospective lenders when preparing the project studies and when negotiating agreements with the Government of the Lao PDR (GOL) as well as with power purchaser(s). The GOL also takes into account the requirements of lending banks, power purchaser(s) and developers when concluding the project agreements. The project documents below are selectively shown for the project financing.

\section{Project Studies Technical Feasibility Study}

The process of development starts with carrying out technical cum financial feasibility studies (FS), as well as environmental and social (E\&S) impact studies and mitigation plans. The technical feasibility study comprises several technical aspects including, but not limited to: geology, hydrology, environment and social considerations. Soil and rock investigations regarding the location of a dam(s), powerhouse, tunnel(s) if any, and other requisite structures must be carried out in order to ensure that the facilities stand firmly once a reservoir has been impounded and the project becomes operational. Boreholes in reservoir areas are tested for possible leakage when the water is later impounded.

Elevation of intake gates at the reservoir and powerhouse must be carefully evaluated to ensure the achievement of maximum head that will result in gaining power from gravity flow of water. The record of rainfall including flow pattern of the river during at least the past 50 years is core hydrological data needed for designing the capacity output vis à vis energy generation of the project.

\section{Environmental and Social Study}

As the construction and operation of the hydropower project may unavoidably create negative impacts on the environment and residents and communities in the area, relevant comprehensive studies and mitigation plans are required to be put in place. Salvage and mitigation plans 
for archeological artifacts and wildlife found in the area shall also be established.

During the development of the environmental and social studies, a series of public consultations are to be carried out so as to ensure that the voices of project affected people are heard and means of addressing their concerns are ultimately incorporated into the project design. Special attention is required to be paid to ethnic minorities, especially indigenous people living in the project area.

\section{Financial and Economic Study}

As a part of the technical feasibility study, the developer is required to undertake a financial study that includes global project cost, split into base project cost and contingency. A comprehensive financial model shall be attached to the financial study so as to demonstrate the financial benefit expected to be received during the operations period. The GOL, employing its own financial model, will carry out a financial and economic analysis by which it can assess its direct financial benefits and indirect benefits to be derived from the development of the project in question. Several financial analysis criteria have to be agreed upon by the GOL and the SPC in order to achieve a financially viable project for investors as well as for the commercial lenders. Incomes of the project are controlled by a negotiated and agreed electricity tariff that is contractually fixed for whole period of the Power Purchase Agreement.

A minimum required equity internal rate of return for the project investors and an obligatory debt service coverage ratio for the commercial lenders are financial thresholds that must be determined and agreed upon by the parties. Given the nature of hydropower project in Laos and the risks associated with their implementation, developers generally target an equity internal rate of return (EIRR) of at least 12\%. The SPC is required by its lenders to maintain project cash flow enabling it to repay its debt and interest thereon. To ensure that this can be done, the SPC is generally obliged to establish a debt service reserve account sufficient to service six months of debt, and also to effect various types and amounts of insurance coverage to address certain costs of project repair or business interruption. Lenders typically require the SPC to maintain at least a minimum debt service coverage ratio (DSCR) throughout the debt service period which shall be at least 1.3:1.

The financial benefits of the GOL in the form of resource usage levies and taxes are negotiated, taking into account financial privileges such as tax holiday and exemptions agreed upon in the Concession Agreement. In addition to the financial and economic determinants, the GOL may also take into consideration such other factors as it may deem relevant, on a project by project basis, including the enhanced availability of power for local usage and rural electrification, project dividends earned by an Lao state-owned enterprise which may also be a shareholder in the project, the need that other foreign invested projects may have to secure a reliable source of power, and so on.

\section{Study Review}

All such studies and reports must then be made available by the developer to the GOL, the potential electricity buyer, and the financiers for their respective review and due diligence. The developer bears all costs associated with the foregoing studies and mitigation actions as contemplated in the studies, which costs are treated as project development costs once the SPC has been established. Only when the project has been proven feasible is the developer allowed to proceed with the next steps.

\section{Project Agreements}

There is a web of agreements amongst parties involved in the project development. The developer is obliged to establish the SPC under Lao law before entering into the project agreements. The SPC is party to each of the agreements described below, each with a different counterparty or counterparties.

\section{Concession Agreement}

The Concession Agreement (CA) is an agreement between the GOL and the SPC. The CA contains detailed obligations and rights of the parties including negotiated provisions regarding statutorily imposed taxes (corporate income taxes, royalties, import duties, etc.) payable by the SPC to the GOL in exchange for the concession rights and financial privileges granted by the GOL to the SPC. In order to attract foreign direct investment into the Lao power sector (often undertaken in remote areas where supporting infrastructure - roads, accommodations, etc. is not adequate and must also be developed as needed for the project), several statutory taxes that would ordinarily be payable by the concessionaire and its contractors have been waived. Construction materials, vehicles and equipments are imported into Laos with import duty exemption. Foreign labor may be temporarily imported into the country to fill the shortage of skilled labor that a project would otherwise encounter. Off-shore banking operations have been permitted for the SPC in an unfettered manner.

The parties also agree on such matters as dispute resolution and governing law, and the consequences of events of default and force majeure. The CA is the foundation upon which all other project documents must rest - as such, it may not be contradicted or over-ruled by the provisions of any other agreements, including the power purchase agreement and the credit facility agreement. The CA is written and signed in English.

\section{Power Purchase Agreement}

The SPC must also conclude a power purchase agreement (PPA) that includes a long term take-or-pay commitment, in order to ensure that the SPC will have available sufficient cash flow to repay its debts and interest to lenders and to cover its operating costs. Most of the Lao 
hydropower projects supplying electricity to Thailand's government-owned offtaker, the Electricity Generating Authority of Thailand (EGAT), do so on an intermediate peaking basis, under which EGAT dispatches the facility on average 16 hours per day and six days a week. There is no supply on Sundays and public holidays (EGAT meets its reduced power needs for Thai customers on those days from its own generating assets).

The tariff applied to electricity supplied from Lao projects is based on the system of EGAT's avoided cost. The system of avoided cost is one in which the long run marginal cost for the same amount of energy acquired through another means (such as the construction of a new power plant or purchase from a new supplier) is calculated from fixed capital cost, expenses such as variable operation and maintenance cost, and projected fuel expense over a specified time horizon.

The cost of electricity from a power plant that would otherwise be required to be constructed by EGAT in Thailand is EGAT's system avoided cost. For a variety of reasons, the EGAT system avoided cost is usually higher than the tariff of electricity imported from Laos when calculated at the delivery point (usually determined to be at the border). This difference in system avoided cost and an acceptable tariff is what makes such projects viable. Only the difference between the generation cost of the Lao project and EGAT's system avoided cost will be negotiated in the relevant project agreements and shared amongst the power buyer, the SPC and the GOL. The Energy Tariff for power purchased from Laos comprises the Thai system avoided cost minus the cost of new or upgraded transmission system investments required to be made by EGAT on the Thai side of the border.

The power purchase agreement is supported by a direct agreement to be signed between EGAT and the GOL. By entering into the direct agreement, the GOL acknowledges certain step-in rights that may be exercised by EGAT when triggered by the SPC's failure to operate the facilities in accordance with the provisions of the off-take agreement as so signed. The GOL also makes representations to that off-taker that the SPC has satisfied all of its submitted environmental and social mitigation plans. The GOL is also obliged to remedy any consequences of its own acts or of Lao sovereign events that adversely affect the implementation of the off-take agreement or the rights of the parties thereto.

\section{Credit Facility Agreements}

Debt finance is raised from international private banks and collateralized with, inter alia, a pledge of share certificates, mortgage of the project's assets, key project agreements and other documents, leasehold interest of the project, insurance proceeds, and the project's future cash flow. Debt financing is syndicated by one or two banks depending upon the currency composition of the amounts borrowed. Debt financing partly, or wholly, covers reimbursement to the developer of its costs of project preparation, environmental and social mitigation, civil works, equipment, and related infrastructure.

\section{Construction/Supply Contracts}

Once all financing sources have been secured by signing all financing agreements, financial closure will be declared. Upon achieving the financial closure, the SPC will sign construction and supply contracts with different contractors and suppliers. The construction may be undertaken by means of an engineering-procurementconstruction (EPC) arrangement, or may be split into different packages such as civil and electro-mechanical parts. The contractors and suppliers enjoy privileges such as special tax treatment, and also become responsible for liabilities related to delay or breach of contract in accordance with the provisions of the CA through the SPC.

If the construction is undertaken through an EPC arrangement, the SPC will incur a project management fee and limited risk premium payable to the EPC contractor. If the SPC directly contracts all project works to different principal contractors, the SPC will not need to pay any project management fee to any contractor, but must shoulder all risks associated with cost overruns and liquidated damages upon delay. For projects where EGAT is the intended offtaker, the level of liquidated damages payable in various circumstances can be significant.

\section{Development Requirements}

A project developer must design the project in a manner that ensures it will be technically, financially, and economically sound. Projects are to be implemented in accordance with the social and environmental safeguard policies of the World Bank (WB). WB guidelines followed for all projects. Costs of environmental and social mitigation are borne by the SPC and, as such, are recognized as project costs. Broad understanding by and support from civil society are of key importance to the project's acceptance and success. In gaining such support, the project's rationale and the benefits that will flow from the project to the people of Laos and to the GOL must be effectively communicated in a process of balanced consultation with and among domestic and international stakeholders.

The Concession Agreement between the GOL and the SPC requires the GOL to grant exclusive concession rights over the project to the SPC for the duration of the concession period, to waive its sovereign immunity, and to be financially liable for the consequences of political force majeure, subsequent changes in Lao law, and the sovereign acts of Laos. In addition, in the CA the GOL accepts neutral (third country) arbitration and commits to maintain its ratification of the New York Convention of 1958 on the enforcement of arbitral awards.

\section{Benefit Sharing}

The project shall yield profits to all participants particularly the GOL, the SPC and EGAT. EGAT benefits from its import of electricity from Laos, obtaining such 
electricity at a cost lower than that which EGAT would be required to incur to produce an equivalent amount of power in Thailand. The SPC obtains its financial benefit measured with a satisfactory and investible equity internal rate of return (EIRR). The GOL has both direct benefits, through the collection of resource usage levies and corporate income tax, and indirect benefits by enhancing ancillary development such as flood control, irrigation from tail water, aquatic culture in the reservoir, and other rural development activities which are valued in both financial and economic terms.

Xaypaseuth Phomsoupha has been working and has taken several executive positions in the Lao energy sector since 1991 before being appointed Director General of Energy Business Department in 2011. He has been directly responsible for drafting and negotiating legal documents for non-recourse financing of a number of IPP projects that are now supplying electricity to Thailand and several others that are currently under construction. Presently he is the chief negotiator leading the government team to negotiate concession agreements and other relevant project agreements to which the government of Laos is party. He has also been involved in negotiation on power purchase agreements and credit facilities agreements of IPP projects for the supply of electricity to the domestic grid, as well as to Thailand, Cambodia and Vietnam. Following his earlier formal training in economics he graduated with Master's Degree at the Australian National University in Canberra.

Corresponding Address: xaypaseuth@laopdr.com

\section{Relevant References}

EPD, 2011, First Quarter Progress and Evaluation Report, Vientiane, Laos: Energy Promotion and Development Department.

Ministry of Energy and Mines, 2007, National Policy on Environmental and Social Sustainability of the Hydropower Sector in Lao PDR, Vientiane, Laos: Ministry of Energy and Mines.

Perkins, F., 1994, Practical Cost Benefit Analysis, Sydney: Macmillan Education Australia Pty Ltd.

Yescombe, E., 2002, Principles of Project Finance, London: Academic Press.

\section{CALENDAR OF EVENTS - HYDROPOWER AND ELECTRICAL SYSTEMS}

14-15 February, 2012: Conference on Dams and Hydropower in Iran. Location: Tehran, Iran. Contact Email: info@icdhp.com. More info: www. icdhp.com.

5-7 March, 2012: HydroVision Russia sponsored by PennWell Corporation. Location: Moscow, Russia. Contact Email: mathildes@pennwell.com. More info: www.hydrovision-russia.com.

12-16 March, 2012: Contractual and Legal Aspects in Hydropower Development. Location: Trondheim, Norway. More info: www.ich.no/DynamicCourses. asp? ID $=57$.

16-18 April, 2012: Hydro Costa Rica 2012 sponsored by Instituto Costariccense de Electricidad and International Centre for Hydropower. Location: San Jose, Costa Rica. More info: www. hydrocostarica2012.org.

19-21 April, 2012: HydroVision India sponsored by PennWell Corporation. Location: New Delhi, India. Contact Email: amyn@pennwell.com. More info: www.hydropowerindia.com.

26-27 April, 2012: 4th Annual Managing Regulatory Compliance for Electric Utilities. Location: Atlanta, USA. Contact Email: lisaeg@marcusevansch.com.

7-12 May, 2012: Small Hydro Resources. Location: Trondheim, Norway. More info: www.ich.no/ DynamicCourses.asp?ID=58.

15 May, 2012: Clean Power Asia 2012. Location: Bali, Indonesia. Contact Email: info@synergy-events. com.
23-26 May, 2012: Hidroenergia 2012 sponsored by Polish Association for Small Hydropower Development and European Small Hydropower Association. Location: Wroclaw, Poland. More info: www.2012.hidroenergia.eu.

17-20 July, 2012: HydroVision International. Location: Louisvilie, KY, USA. More info: www. hydroworld.com/index/events.

20 August to 6 September, 2012: Hydropower and the Environment. Location: Trondheim, Norway. More info: www.ich.no/DynamicCourses. asp? ID $=59$.

26-31 August, 2012: International Council on Large Electric Systems. Location: Paris. Contact Email: sylvie.bourneuf@cigre.org. More info: www.cigre. org.

24-27 September, 2012: 3rd International Conference on Sustainable Energy Technology (ICSET'12). Kathmandu, Nepal. More info: www. ieee-icset.org/index.html.

25-27 September, 2012: HydroVision Brasil. Location: Rio de Janeiro, Brasil. More info: www. hydroworld.com/index/events.

8-12 October, 2012: Risk Management in Hydropower Development. Location: Trondheim, Norway. More info: www.ich.no/DynamicCourses. asp? $\mathrm{ID}=60$.

29-31 October, 2012: Hydro 2012, International conference and Exhibition. Location: Bilbao, Spain. More info: www.hydropower-dams.com. 